\title{
Fertilizer use optimization approach: An innovation to increase agricultural profitability for African farmers
}

\author{
H. Rware ${ }^{1 *}$, C. Kayuki ${ }^{2}$, M. Macharia ${ }^{1}$ and G. Oduor ${ }^{1}$ \\ ${ }^{1}$ Centre for Agriculture Bio science International, Uganda. \\ ${ }^{2}$ National Agricultural Research Organization (NARO), Uganda.
}

Received 8 July, 2016; Accepted 1 September, 2016

\begin{abstract}
Farmers in Africa have not been fully convinced to invest in fertilizer due to uncertainty on returns to investment. This is despite the fact that, more than two-thirds of people in Sub-Saharan Africa rely on agriculture for employment with many living on small farms earning less than $\$ 1$ per day. Usage of fertilizer has remained low and stagnant hence the yields in have been persistently lower than other parts of the world. To address the plight of the smallholder farmers' inability to optimize productivity in fertilizer use, a collaborative research project Optimization of Fertilizer Recommendations in African (OFRA) 2013 to 2016 was designed through the Alliance for Green Revolution in Africa (AGRA) funding, implemented by Centre for Agriculture and Biosciences International (CABI) and science support by the University of Nebraska Lincoln (UNL). Broad objective was to develop AEZs and crop specific fertilizer recommendations for 13 SSA countries and development of fertilizer optimization approach for smallholder farmers to maximize returns to investment. This paper describes the optimization approach and how it works for farmers benefits. About 65 agro ecological zones (AEZs) specific fertilizer optimization tools (FOTs) for 14 important SSA crops (54\%) were developed. Two complimentary tools the paper too and nutrient substitution table were developed to work concurrently with the FOT.
\end{abstract}

Key words: Optimization, profitability, farmers, approach, Africa, fertilizer optimization tools (FOTs), agro ecological zones (AEZs).

\section{INTRODUCTION}

Farmers in Africa have not been fully convinced to invest in fertilizer owing to the uncertainty of returns to investment. This is despite the fact that, more than twothirds of people in Sub-Saharan Africa rely on agriculture for employment and many of them live on small farms and earn less than $\$ 1$ per day and as such, the usage of fertilizer remains low and stagnant hence the yields in have been persistently lower than other parts of the world. Moreover, there has been a mixture of trend from high soil nutrient deficits and very low fertilizer use $3 \%$ of global fertilizer consumption; $7 \mathrm{~kg} / \mathrm{ha}$ versus $>150 \mathrm{~kg} / \mathrm{ha}$ in Asia) World Bank (2007). It is as a result of this the average yield of cereals and average intensity of modern inputs has stagnated in contrast to what has been observed in most developing regions, World Bank (2007). Most often when they apply fertilizer, the smallholder

*Correspondent author. E-mail: h.rware@cabi.org.

Author(s) agree that this article remain permanently open access under the terms of the Creative Commons Attribution License 4.0 International License 
farmers in Africa, do it to only a small part of their farm, since they have to make choices that maximize the benefit-to-cost ratio; where fertilizer applications is based on the crop-nutrient rate combinations that gives the greatest net returns for their investment (Kaizzi et al., 2012a). However, existing fertilizer recommendations do not allow farmers to maximize net returns on their investment. In addition to these issues a lack of information about correct application rates, timings, and the use of the correct products for different crops compounds the problems associated with blanket fertilizer recommendations (Rware et al., 2014).

Responding to these myriad of problems facing the farming community in Africa, several governments in SSA in partnership with international and regional bodies introduced inputs subsidy programs as immediate solutions with a view to fostering the use of contemporary inputs and increase agricultural productivity (Druilhe and Barreiro-Hurlé, 2012; Jayne and Rashid, 2013). However, Tavneet Suri (2007), found that on the realization that the fertilizer requires many other complementary inputs, or be risky, many countries have either withdrawn or scaled back fertilizer subsidies, in part because of fiscal constraints and other related barriers such as corruption and inefficiency in the administration of fertilizer subsidies.

The objective fertilizer recommendations in Africa are maximizing yield or profit per hectare. This only satisfies the need for farmers with good financial abilities to apply fertilizer across their entire crop land to maximize net returns per hectare (Kaizzi et al., 2015). Most initiatives have focussed advocating for use of fertilizer to increase crop yields for the food security in Africa. However, with the recent clarion call for farmers to practice farming as a business, there is a paradigm shift on the real focus by farmers is maximising returns to fertilizer investment. The small holder farmers are more focused in using fertilizer for increased yields and get increased returns to investment given their little income for farming inputs (Rware et al., 2014). This paper therefore, addresses the process of developing a fertilizer use optimization approach with the extension workers using the optimization approach to advice farmers to optimize returns from fertilizer use.

To further come up with tailor made solutions to the plight of the small holder farmers' inability to optimize productivity, a collaborative research project optimization of fertilizer recommendations in African (OFRA) 2013 to 2016 was designed jointly funded by AGRA, implemented by $\mathrm{CABI}$ and science support by the University of Nebraska Lincoln was designed. The project collaborated with the Africa Soil Health Consortium (ASHC) and Africa Soil Information Services (AfSIS) and National Research Organizations in Burkina Faso, Ethiopia, Ghana, Kenya, Malawi, Mali, Niger, Nigeria, Mozambique, Rwanda, Tanzania, Uganda and Zambia. The broad objective was to develop agro ecological zones (AEZs) specific and crop specific crop response functions for the 13 African countries and development of the fertilizer use optimization approach to address the plight of the smallholder farmers who have little to invest in fertilizer purchases and help them maximize returns to investment on fertilizer and be able to make better choices on which crops would give most returns if fertilizer is applied. This paper discusses the use of the optimization approach to maximize net returns for the farmer's in the economic and agronomic context. The real problem why the approach is needed, and the relevant basic principles and describes how the approach was developed, the tools that support the approach, the requirements in the roll out of the approach and the sustainability considerations of the approach.

\section{METHODOLOGY}

Development of the fertilizer use optimization approach in OFRA involved reviewing of past literature on crop nutrient, soil fertility, fertilizer recommendation and general crop response research. This was to identify gaps in relation to crop nutrient response functions and fertilizer recommendations and given an indication to where OFRA trials could be located. The gaps were filled through establishment of trials across 13 different countries in the SSA. The countries were picked because they fell in the list of the chore countries focused into by the AGRA (financing organization). UNL provided quality control of the data and the science aspects of the project. Further, the choice of crops in countries was informed by the position of this crops in the policy whether an important food crop or source of income for the country as well as for the small holder farmers. A standard protocol for establishing the trials and soil and foliar sampling was developed by the science leader in consultation with the country PIs from the 13 countries to guide the PIs in conducting their trials. Selection of trial sites was guided by use of the GIS tool and AEZs, areas considered as country food basket, areas where past research was done and the knowledge of the country teams in relation to the AEZs. AfSIS ensured that the comprehensive database is linked to geo-referenced soil, climate and remote sensing data. Spatial information from AfSIS enhanced accurate and efficient use of the agronomy field research data in the OFRA/SHC database.

\section{Optimization approach}

There is generally low use of fertilizer by the smallholder in Africa which largely affects their productivity levels. This is exacerbated by the fact that many of these farmers do not have the financial capacity to use enough fertilizer to maximize net returns per hectare. This is addition to the high fertilizer costs and low commodity prices, associated with costly input supply and inefficient marketing channels; the farmers profit potential is highly reduced. These smallholder farmers have more than one competing needs for the little cash they have and the most pressing need often take priority especially when profitability of fertilizer use is not convincing. These farmers therefore need high net returns on their investments in fertilizer use if they have to embrace the fertilizer use technology in their farms (Kaizzi et al., 2013). Optimization approach is achieved by allocating fertilizer to an optimized choice of crop-nutrient-rate combinations where the farmer gets good returns to investment.

The profitability of different crop-nutrient combinations varies with the relative value of crops, the costs of fertilizer nutrients, the magnitude of each crop's response to an applied nutrient, and the shape of the response curve. Nutrient application continues in a 


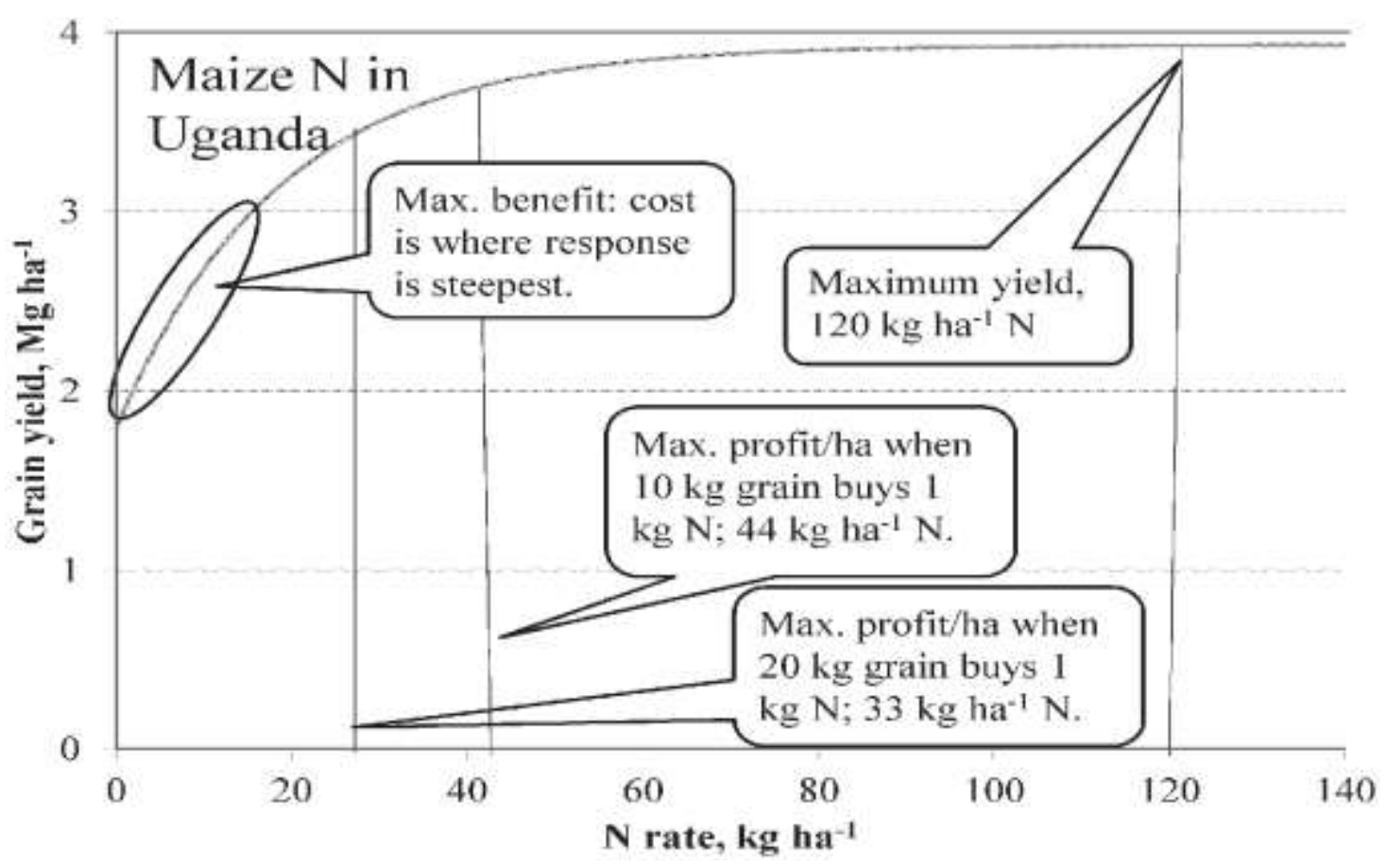

Figure 1. Maize yield response to $\mathrm{N}$ fertilizers and effect of change in cost of nutrient to farm gate price on the economically optimum amount of fertilizers (Jansen et al., 2013).

curvilinear trend until yield reaches a plateau. However, yields sometimes does decrease from a peak with high application rates may be due to localized fertilizer salt effects, severe soil water depletion at a critical growth stage following a period of vigorous growth, increased disease, or more lodging (Kaizzi et al., 2015). A method of optimizing across these response functions was developed to determine the allocation of fertilizer investment to the crop-nutrient-rate combinations that maximize net returns on investment. Whereas large scale farmers have adequate finance may strive to maximize net returns per hectare resulting from fertilizer use, majority of the smallholder farmers have meagre opportunities for improvement and are largely vulnerable to agricultural shocks.

Reliable crop-nutrient response functions for an agro-ecological zone are essential for estimating likely profitability of crop-nutrient rate decisions. These functions can be determined using results from locally conducted research and extrapolation of results from other locations with similar growing conditions. Smallholder farms often produce four or more substantial crops and optimization of fertilizer use may involve 12 or more crop-nutrient combinations to determine the optimal rate for a farmer's situation. A computerbased fertilizer optimization tool and its paper version are described (Charles and Kaizzi, 2015). In Figure 1, the crop-nutrient response is represented by an asymptotic function such as $Y=a-b c^{N}$, where $Y$ is yield, $a$ is yield at the plateau, $b$ is the possible yield increase resulting from nutrient application, $c$ is a curvature coefficient giving an abrupt response at low $c$ values and having a value of 1 with a linear response, and $\mathrm{N}$ is the nutrient application rate (Kaizzi et al., 2012c). If cash is not a constraint, the amount of fertilizer that maximizes returns per area of land Economically Optimum Rates (EOR) can be applied. But if financially constrained, the amount of fertilizer that maximizes returns per shilling invested, which is less than the EOR, should be applied. If farm gate prices of produce decline or fertilizer prices increase, farmers have to apply less fertilizer to maintain the EORs. For example, in trials carried out in Uganda (Figure 1), the EOR for maize decreased from 44 to $33 \mathrm{~kg} \mathrm{~N} / \mathrm{ha}$ as C: $\mathrm{P}$ increased from 10 to 20 . For cash constrained farmers, maximum benefits, that is, highest benefit-to-cost ratio (region indicated with oval) could be obtained by applying less than $30 \mathrm{~kg} \mathrm{~N} / \mathrm{ha}$ (Jansen et al., 2013).

\section{RESULTS AND DISCUSSION}

\section{The fertilizer optimization tool (FOT)}

Fertilizer Optimization tool is the main tool in the optimization approach that was developed. It is available in three versions (computer excel, the paper and the mobile app version). In OFRA project the mobile app was developed and tested in Uganda in partnership with Grameen Foundation. Despite the fact that it was the most preferred and going by the mobile role in extension in the current world, the mobile app did not continue due to funding challenges. A total of 65 AEZs and crop specific FOTs were developed across 13 countries as shown in Table 1, in consideration of the pats research and field trials data. Important to note is that the crops covered by the project represent about $54 \%$ of important crops in Africa.

\section{Optimization working principle}

The Optimizer uses linear programming concepts using Excel with the Solver add-in the extension worker and 
Table 1. FOTs developed for the different Crops and AEZs in 13 OFRA countries.

\begin{tabular}{|c|c|c|c|}
\hline $\mathbf{S} / \mathbf{N}$ & AEZ & Elevation (M) & Crops \\
\hline & Kenya & & \\
\hline 1 & Western Kenya & $>1400 \mathrm{~m}$ & $\begin{array}{l}\text { Maize, Irish potato, sweet potato, lowland rice, maize-bean, } \\
\text { climbing bean, wheat }\end{array}$ \\
\hline 2 & Western Kenya & $<1600$ & Maize, sorghum, finger millet, beans, groundnut \\
\hline 3 & Central Kenya & & Maize, beans, maize-beans, rice, wheat \\
\hline 4 & Coastal area & & Cassava, maize, lowland rice, sorghum, finger millet, cowpea \\
\hline 5 & Eastern Kenya & $>1200 \mathrm{~m}$ & Banana, Irish potato, maize, maize-bean, lowland rice, bean \\
\hline 6 & Eastern Kenya & $<1200 \mathrm{~m}$ & Maize, beans, sorghum, Irish potato \\
\hline 7 & Rift Valley & $>2000 \mathrm{~m}$ & Maize, Irish potato, beans, wheat, maize-bean, green gram \\
\hline \multirow[t]{2}{*}{8} & Rift Valley & $<2100 \mathrm{~m}$ & $\begin{array}{l}\text { Maize, soybean, Irish potato, beans, wheat, maize-bean, } \\
\text { green gram }\end{array}$ \\
\hline & Rwanda & & \\
\hline 9 & Eastern region & $<1800$ & Banana, maize, sorghum, lowland rice, beans, soybean \\
\hline 10 & Northwest highlands & $>1800 \mathrm{~m}$ & $\begin{array}{l}\text { Wheat, Irish potatoes, maize, climbing bean, soybean, } \\
\text { banana, bean }\end{array}$ \\
\hline \multirow[t]{2}{*}{11} & Southern Rwanda & & $\begin{array}{l}\text { Wheat, maize, climbing bean, lowland rice, beans, soybeans, } \\
\text { sweet potato }\end{array}$ \\
\hline & Tanzania & & \\
\hline 11 & Central zone & & Lowland rice, maize, sorghum, sweet potato, cowpea \\
\hline 12 & Eastern zone & & Lowland rice, cassava, maize, sorghum, cowpea \\
\hline 13 & Lake zone & $>1300 \mathrm{~m}$ & Maize, Irish potato, finger millet, sweet potato, bean, banana \\
\hline 14 & Lake zone & $<1400 \mathrm{~m}$ & $\begin{array}{l}\text { Lowland rice, maize, sweet potato, sorghum, beans, finger } \\
\text { millet }\end{array}$ \\
\hline 15 & Northern & & Lowland rice, maize, wheat, beans, finger millet \\
\hline 16 & Southern zone & & Lowland rice, maize, sorghum, cowpea, cassava, groundnut \\
\hline 17 & Southern highlands & & Lowland rice, maize, sorghum, bean, wheat \\
\hline \multirow[t]{2}{*}{18} & Western zone & & $\begin{array}{l}\text { Lowland rice, maize, sorghum, sweet potato, soybean, } \\
\text { groundnut }\end{array}$ \\
\hline & Uganda & & \\
\hline 19 & Eastern Uganda & $1400-1800 \mathrm{~m}$ & Maize, banana, Irish potatoes, beans, soybeans, groundnut \\
\hline 20 & Eastern Uganda & $>1800 \mathrm{~m}$ & Maize, banana, wheat, beans, soybean, groundnut \\
\hline 21 & Eastern Uganda-Lake Kyoga basin & $>1800$ & $\begin{array}{l}\text { Upland rice, maize, sorghum, soybean, finger millet, beans, } \\
\text { groundnut }\end{array}$ \\
\hline 22 & $\begin{array}{l}\text { Western highlands Kamwenge, Ibanda, } \\
\text { Bushenyi, Kyenjojo }\end{array}$ & & Maize, banana, Irish potato, beans, finger millet, soybean \\
\hline 23 & Western highlands & $>1800 \mathrm{~m}$ & Maize, Irish potato, wheat, beans \\
\hline 24 & Central Uganda & & Maize, banana, upland rice, beans, soybean, groundnut \\
\hline \multirow[t]{2}{*}{25} & North, Midwest \& West & & $\begin{array}{l}\text { Upland rice, maize, sorghum, soybean, finger millet, beans, } \\
\text { groundnut }\end{array}$ \\
\hline & Ethiopia & & \\
\hline 26 & Cold to very cold sub-afro Alpine & $>2500$ & Barley, wheat, faba bean \\
\hline 27 & Hot to warm moist lowlands $9 \mathrm{~N}$ degrees & & Maize, sorghum, lowland rice, teff, beans, soybean \\
\hline 28 & Hot to warm moist lowlands 9S degrees & & Maize, sorghum, lowland rice, teff, beans, soybean \\
\hline 29 & Hot to warm sub-humid and drier lowlands & $<1000$ & Rice, sorghum, maize, teff \\
\hline 30 & Hot to warm sub-moist and drier lowlands & $1000-1800$ & Maize, sorghum, rice, finger millet, teff, soybean \\
\hline 31 & Tepid to cold humid mid high lands & $1700-2200$ & Maize, sorghum, teff, barley, faba bean \\
\hline 32 & Tepid to cold humid mid highlands & $2000-2700$ & Maize, wheat, barley, faba bean \\
\hline 33 & Tepid to cold moist mid high lands & $1700-2200$ & Rice, teff, maize, bean, faba bean, sorghum \\
\hline 34 & Tepid to cold moist mid highlands & $2000-2700$ & Barley, teff, wheat, maize, faba bean \\
\hline 35 & Tepid to cold sub-humid mid highlands & $1700-2200$ & Sorghum, teff, maize \\
\hline 36 & Tepid to cold sub-humid mid highlands & $2000-2700$ & Barley, wheat, faba Bean, Irish potato \\
\hline 37 & Tepid to cold sub-moist mid highlands & $1700-2200$ & Maize, teff, sorghum, bean, faba bean \\
\hline
\end{tabular}


Table 1. Contd.

\begin{tabular}{|c|c|c|c|}
\hline 38 & $\begin{array}{l}\text { Tepid to cold sub-moist mid } \\
\text { highlands } \\
\text { Zambia }\end{array}$ & $2000-2700$ & Barley, maize, teff, wheat, faba bean \\
\hline 39 & Zone 1 & & Maize, soybean, sorghum, groundnut, cowpea \\
\hline 40 & Zone 2 & & Maize, cowpea, beans, soybean \\
\hline 41 & $\begin{array}{l}\text { Zone } 3 \\
\text { Malawi }\end{array}$ & & Maize, cowpea, beans, sorghum, soybean \\
\hline 42 & Lakeshore, middle \& upper Shire & $200-760 \mathrm{~m}$ & Maize, cowpea, bean, soybean, pigeon pea \\
\hline 43 & Mid-elevation, upland plateau & $760-1300 \mathrm{~m}$ & Maize, cowpea, beans, soybean, pigeon pea \\
\hline 44 & $\begin{array}{l}\text { Highlands } \\
\text { Mozambique }\end{array}$ & $>1300 \mathrm{~m}$ & Maize, cowpea, beans, soybean, sorghum, pigeon pea \\
\hline 45 & Western & $900-1300 \mathrm{~m}$ & Maize, cowpea, bean, soybean \\
\hline 46 & Western & $>1300 \mathrm{~m}$ & Maize, sorghum, beans, cowpea, soybean \\
\hline 47 & Burkina Faso & $<900 \mathrm{~m}$ & Maize, cowpea, beans, sorghum, soybean, pigeon pea \\
\hline 48 & North Sudan Savana & & Lowland rice, maize, sorghum, cowpea, groundnut, soybean, pearl millet \\
\hline 49 & Sahel & & Pearl millet, sorghum, groundnut, cowpea, maize, rice \\
\hline 50 & South Sudan Savana & & $\begin{array}{l}\text { Maize, upland rice, sorghum, lowland rice, cowpea, groundnut, pearl } \\
\text { millet }\end{array}$ \\
\hline & Nigeria & & \\
\hline 51 & North Guinea Savannah & & Cowpea, groundnut, maize, lowland rice, upland rice, sorghum \\
\hline 52 & South Guinea Savannah & & Upland rice, lowland rice, groundnut, cowpea, sorghum, soybean \\
\hline 53 & Sahel & & Pearl millet, sorghum, groundnut, cowpea, maize, rice \\
\hline 54 & Sudan Savannah & & Maize, groundnut, lowland rice, sorghum, cowpea, soybean, pearl millet \\
\hline 55 & Derived Savannah & & Maize, sorghum, upland rice, lowland rice, groundnut, soybean \\
\hline 56 & Mid-altitude & & $\begin{array}{l}\text { Lowland rice, maize, sorghum, cassava, groundnut, soybean, upland } \\
\text { rice }\end{array}$ \\
\hline & Niger & & \\
\hline 57 & Sahel & & Pearl millet, sorghum, groundnut, cowpea, maize, rice \\
\hline 58 & $\begin{array}{l}\text { North Sudan Savannah } \\
\text { Mali }\end{array}$ & & Lowland rice, maize, sorghum, cowpea, groundnut, soybean, pearl millet \\
\hline 59 & Sahel & & Pearl millet, sorghum, groundnut, cowpea, maize, rice \\
\hline 60 & North Sudan Savannah & & Lowland rice, maize, sorghum, cowpea, groundnut, soybean, pearl millet \\
\hline 61 & $\begin{array}{l}\text { South Sudan Savannah } \\
\text { Ghana }\end{array}$ & & Maize, upland rice, lowland rice, sorghum, cowpea, soybean, pearl millet \\
\hline 62 & Derived Savanna/ Transitional & & Maize, sorghum, upland rice, lowland rice, groundnut, soybean \\
\hline 63 & North Guinea Savannah & & Cowpea, groundnut, maize, upland rice, lowland rice, Sorghum \\
\hline 64 & North Sudan Savannah & & Lowland rice, maize, sorghum, cowpea, groundnut, soybean, pearl millet \\
\hline 65 & South Sudan Savannah & & Maize, upland rice, lowland rice, sorghum, cowpea, soybean, pearl millet \\
\hline
\end{tabular}

farmer together enter the acreage of the various crops being grown, the price of fertilizers available, the expected price for crop outputs and how much money the farmer has to invest in fertilizer. They then press the 'optimize' tab. The output includes the recommendations for fertilizers to be applied to each crop, the expected mean effect on yield and net returns for each crop, and the expected total net returns. Figures 1 to 3 gives a stepwise process of how the FOT runs the optimization process. The extension worker (any) intermediary asks the farmer the amount of land the farmer want to set aside for each crop in that particular season. In the input section of the optimizer, the intermediary using the knowledge of the farmer, or market trends information puts the expected grain value. Then the extension asks the farmer how much he/she want to spend or invest in fertilizer purchases that season. The amount to invest is the constraint in this case and then click optimize button. The output section of the FOT shows the mean yield increase and the net returns per crop and the total net 


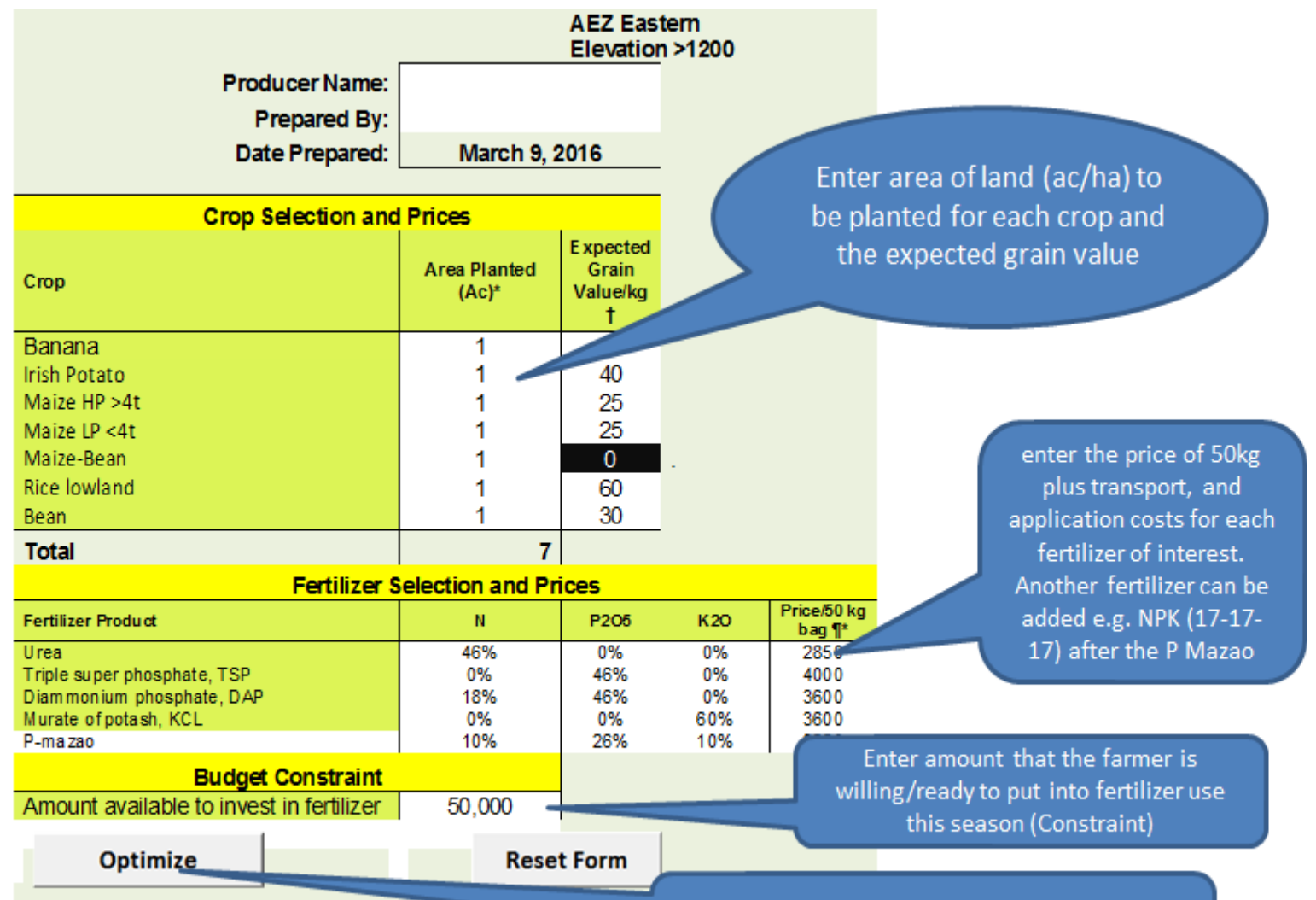

To optimize, left click the optimizer button

Figure 2. Input into the fertilizer optimizer tool.

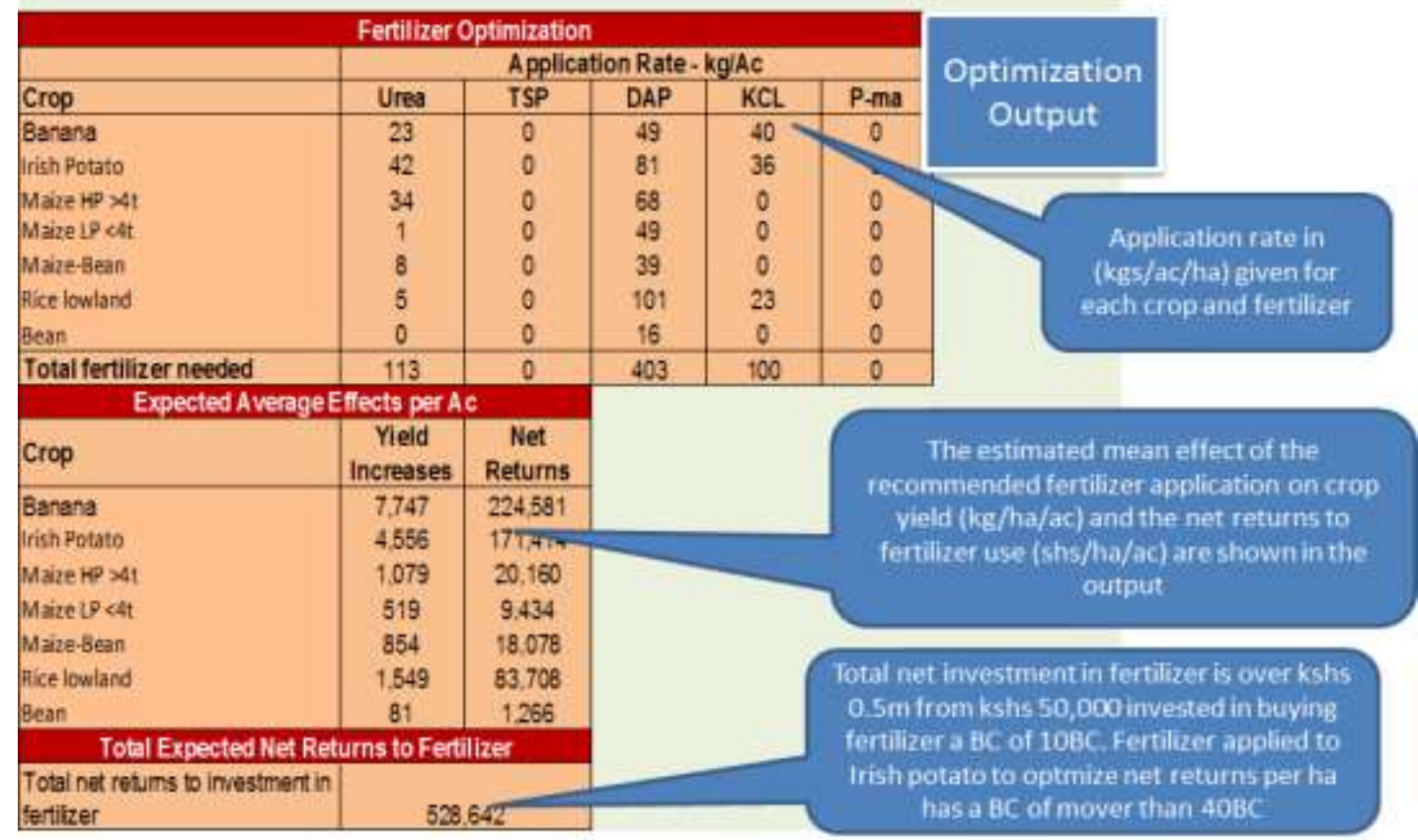

Figure 3. Output from FOT with Kshs. 50,000 invested. 


\begin{tabular}{|l|c|c|c|c|c|}
\hline \multicolumn{5}{c|}{ Fertilizer Optimization } \\
\hline Crop & \multicolumn{5}{c|}{ Application Rate - kg/Ac } \\
\hline Banana & Urea & TSP & DAP & KCL & P-ma \\
\hline Irish Potato & 23 & 0 & 49 & 40 & 0 \\
Maize HP >4t & 42 & 0 & 81 & 36 & 0 \\
Maize LP <4t & 34 & 0 & 68 & 0 & 0 \\
Maize-Bean & 1 & 0 & 49 & 0 & 0 \\
Rice lowland & 8 & 0 & 39 & 0 & 0 \\
Bean & 5 & 0 & 101 & 23 & 0 \\
\hline Total fertilizer needed & 0 & 0 & 16 & 0 & 0 \\
\hline
\end{tabular}

Key decision making issues:

1. The susgested fertilizer rate may be very low e.g. the $16 \mathrm{kgs} / \mathrm{ha}$ DAP for bean to make any economical sense or able to apply (you have two options)

i) Advise the farmer to allocate this money to other profitable crops nutrients

ii) You can also ask the farmer to mix with other fertilizer for ease of application

2. Rates are often low with small investments. However returns on

investments is high. The increased net returns is expected to enable

Figure 4. Decision making considerations.

return from fertilizer investment. The computer based excel version of the FOT is as shown in Figures 2, 3 and 4.

\section{Tools supporting optimization approach}

Optimization approach cannot function independently. To support the roll out of the approach a set of three complementary tools, based on the principle of fertilizer optimization, were developed for use in over 65 agroecological zones in 13 OFRA countries. The tools are based on data generated from a series of crop-nutrient response trials carried out 13 countries and legacy data from previous research, both prior to and under the auspices of the OFRA project.

The tools are intended to be used by extension workers who have gone through series of training and practical's to understand and be able to use the three tools concurrently to advice the farmers. Working with a farmer, the extension worker uses the set of tools to generate fertilizer recommendations which reflect that farmer's specific circumstances, including acreages of the different crops grown, fertilizer prices, expected crop output prices, how much the farmer can afford to spend on mineral fertilizer that growing season and other relevant farming practices, such as use of manure. The recommendations generated for each farmer will be different, 'tailor-made', but in all cases the solution provided will result in the greatest return on the farmers' investment in fertilizer.

\section{The nutrient substitution table}

It is also referred to as integrated soil fertility management (ISFM) framework is used to adjust the output of the FOT to take into account other ISFM practices the farmer is using that impact on nutrients supply. New fertilizer rate recommendations must consider cropping systems and the effects of ISFM practices on fertilizer need, such as: crop rotations; application of manure or other organic material; compost and annual and perennial green manure/cover crops (Kaizzi et al., 2004, 2006, 2007a,b; Wortmann et al., 2000; Kaizzi and Wortmann, 2001). Estimating fertilizer substitution effects of various ISFM practices requires interpretation of results of numerous relevant studies in consideration of the AEZ, soil type, other agronomic practices, and the farmer's economic decisions. For OFRA, a generic model was developed for Uganda which was adaptable to the diverse cropping systems in the 12 OFRA countries.

The ISFM practices to be included in the look-up table are the use of various types of organic matter (manure, compost, and crop residues), intercropping and rotations with legumes, fallows and the results of selected soil tests. For each practice, Table 2 suggests how the fertilizer recommendations generated by the FOT should be adjusted; for example, for every one ton of farmyard manure applied per hectare, fertilizer equivalent to $6 \mathrm{~kg} \mathrm{~N}$ per hectare could be spared. The extension worker will need to convert the values expressed as amount of each nutrient ( $\mathrm{N}, \mathrm{P}$ or $\mathrm{K}$ ) into the equivalent amount of fertilizer.

\section{Fertilizer calibration tool}

The calibration tool is used to convert the recommendation, expressed as $\mathrm{kg}$ of fertilizer per acre or hectare of land, to a more farmer-friendly measure. Few if any small-scale farmers will have access to scales to 
Table 2. Nutrient substitution table.

\begin{tabular}{|c|c|c|c|}
\hline \multirow{3}{*}{ ISFM practice } & Urea or CAN & DAP or TSP & $\begin{array}{lr}\text { NPK } & 23-21-0+4 S \text { or } \\
23: 10: 5+6 S+1.0 Z n\end{array}$ \\
\hline & \multicolumn{3}{|c|}{ Fertilizer reduction, $\%$ or $\mathrm{kg} / \mathrm{ha}$} \\
\hline & $\mathbf{N}$ & $\mathbf{P}$ & K \\
\hline $\begin{array}{l}\text { Previous crop was a green legume manure (Mucuna, } \\
\text { Crotalaria and Lablab) crop }\end{array}$ & $100 \%$ & $8 \mathrm{~kg}$ & $28 \mathrm{~kg}^{\dagger}$ \\
\hline $\begin{array}{l}\text { Early incorporation of a green legume manure (Mucuna, } \\
\text { Crotalaria and Lablab) crop }\end{array}$ & $57 \mathrm{~kg}$ & $3 \mathrm{~kg}$ & $11 \mathrm{~kg}^{\dagger}$ \\
\hline $\begin{array}{l}\text { Use of agroforestry technologies (e.g. leaf prunings of } \\
\text { Gliricidia, Leucaena, Sesbania, Senna spectabilis) applied, } \\
\text { per } 1 \mathrm{t} \text { of fresh material }\end{array}$ & $10 \mathrm{~kg}$ & $1 \mathrm{~kg}$ & $6 \mathrm{~kg}^{\mathrm{t \dagger}}$ \\
\hline Farmyard manure per $1 \mathrm{t}$ of dry material & $2 \mathrm{~kg}$ & $1 \mathrm{~kg}$ & $1 \mathrm{~kg}$ \\
\hline Residual value of FYM applied for the previous crop, per $1 \mathrm{t}$ & $1 \mathrm{~kg}$ & $0.4 \mathrm{~kg}$ & $0.4 \mathrm{~kg}$ \\
\hline Dairy or poultry manure, per $1 \mathrm{t}$ dry material & $24 \mathrm{~kg}$ & $7 \mathrm{~kg}$ & $14 \mathrm{~kg}$ \\
\hline $\begin{array}{l}\text { Residual value of dairy and poultry manure applied for the } \\
\text { previous crop, per } 1 \mathrm{t}\end{array}$ & $5 \mathrm{~kg}$ & $1.4 \mathrm{~kg}$ & $3 \mathrm{~kg}$ \\
\hline Compost, per 1 t/ha dry wt. & $20 \mathrm{~kg}$ & $1 \mathrm{~kg}$ & $20 \mathrm{~kg}$ \\
\hline Doubled-up legume-technology (pigeon pea) & \multicolumn{3}{|c|}{$\begin{array}{l}\text { In the second year of rotation a mean reduction of over } 50 \\
\mathrm{~kg} \mathrm{~N}^{\mathrm{tt}}\end{array}$} \\
\hline Cereal-bean intercropping & \multicolumn{3}{|c|}{$\begin{array}{l}\text { Increase DAP/TSP by } 18 \mathrm{~kg} / \mathrm{ha} \text {, but no change in } \mathrm{N} \& \mathrm{~K} \\
\text { compared with sole cereal fertilizer }\end{array}$} \\
\hline Cereal-other legume (effective in $\mathrm{N}$ fixation) intercropping & \multicolumn{3}{|c|}{$\begin{array}{l}\text { Increase DAP/TSP by } 20 \mathrm{~kg} / \mathrm{kg} \text {, reduce urea by } 30 \mathrm{~kg} / \mathrm{ha} \text {, \& } \\
\text { no change in } \mathrm{K} \text { compared with sole cereal fertilizer }\end{array}$} \\
\hline If Mehlich III P >18 ppm & \multicolumn{3}{|l|}{ Do not apply P } \\
\hline If soil test $\mathrm{K}<0.25 \mathrm{cmol} / \mathrm{kg}$ & \multicolumn{3}{|c|}{ Apply $20 \mathrm{~kg} \mathrm{KCl} / \mathrm{ha}$} \\
\hline
\end{tabular}

weigh out the fertilizer and not all will know the size of the plots they are using to grow each crop. To overcome this problem, the calibration tool is based on the use of items that are freely available and that can be adapted and used as calibrated measuring scoops. These include cutdown, discarded plastic bottles that previously held water or some other liquid; bottle tops, such as the crimped metal bottle-tops commonly used to cap beer or soda (known as crown corks); or rectangular containers, such as empty match boxes. The calibration tool runs on a laptop but the paper version of the FOT has the calibration factored is shown in Figure 5.

To make it work, first the dimensions of the container to be used are entered; the tool uses these to calculate the volume of the cylindrical or rectangular container. Secondly, the type of fertilizer being used is selected from a drop-down menu: not all fertilizers have the same density, so one bottle-cap full of one fertilizer will have a different weight to the same bottle-cap full of another type of fertilizer. Next the number of $\mathrm{kg}$ of fertilizer to be applied per acre or hectare is entered, along with the method of application (broadcast, banding or point placement, also known as micro-dosing) and the distance between rows and plants within rows. Based on the information provided, the calibration tool provides a userfriendly fertilizer recommendation; for example, instead of $40 \mathrm{~kg}$ DAP per hectare it might suggest a plastic water bottle lid full of DAP applied as a band $2.1 \mathrm{~m}$ long.

\section{Where there are not computes? Paper version of the FOT}

In the optimization approach, the FOT is either in the computer excels solver format, paper format and mobile application (developed and tested in Uganda). One of the major challenge that bedevil sub Saharan Africa extension work is poor resourcefulness and majority do not own laptops and besides, the desktop cannot be effectively be used by the extension. Further, African governments have not financed well the extension arm of the agricultural ministries. In this regard, usage of computer based excel format of the FOT is a big challenge. To address that challenge and continuity of extension services, OFRA developed a paper version of the FOT which considers three levels of farmer financial ability and fertilizer use guidelines are provided based on marginal rate of return. If the farmer has one or more crops in the cropping system, some fertilizer application options have priority over other options as shown in Figure 6 . The paper FOT does need to be updated when there are substantial changes in the costs of fertilizer use relative to commodity values. About $20 \%$ of the profit potential in the decision making is lost with the paper 


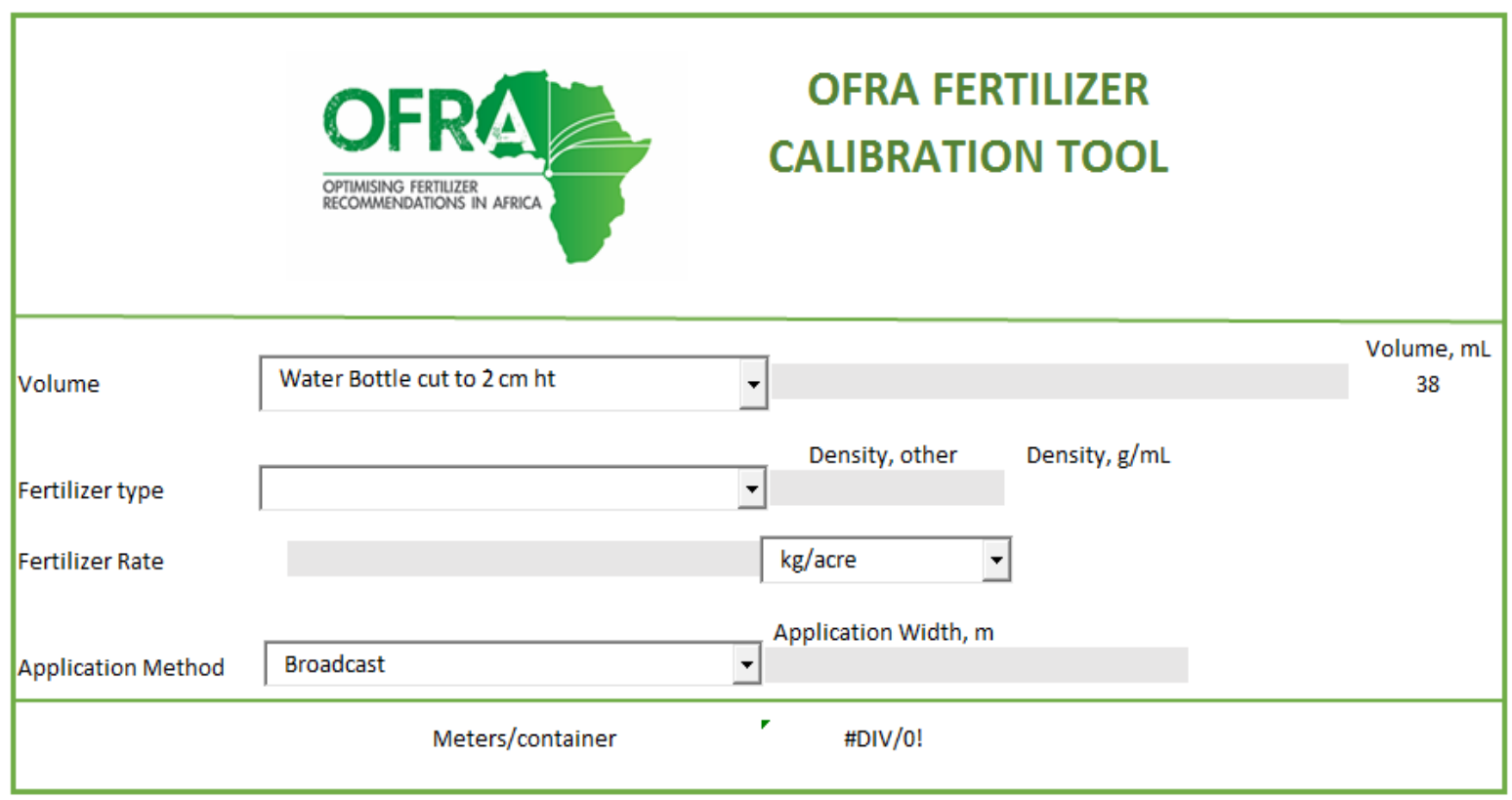

Figure 5. OFRA fertilizer calibration tool.

FOT than the Excel FOT because of the generalization for farmer's budget constraint and selection set choices with financial capability levels (Charles and Kaizzi, 2016), Figure 6 show the example of paper version of the FOT for lower eastern Kenya.

\section{Rolling out the optimization approach}

Rolling out the optimization approach was an important step in delivering OFRA. Initial steps for the roll of were to develop of stakeholder's engagement plan and roll out strategies that were country. This was from the understanding that there are different player/stakeholders in each country and hence requiring a specific approaches. In the modern world overcoming barriers to rolling out an agricultural innovation is next to impossible if broad involvement of all key and relevant stakeholders is not engaged. This is to ensure their buy in, appreciation and eventual ownership of the innovation. At this stage it will be important to develop the demand and supply side to ensure a balanced flow. Players in this stage include extension workers and other government agencies that are vital in mobilizing of smallholder farmers. They should be the first people to be trained to understand the approach and how to use the approach in advising farmers. They are also better placed to linking the optimization approach with government's fertilizer subsidy and distribution channels including the agrodealers. In Uganda MAAIFS expressed interest to use the approach in its fertilizer subsidy program for 2016/2017 financial year.
Given the diversity in the stakeholders involved in rolling out of the optimization approach communication support is critical to ensure that there harmonized messages are passed to all the stakeholders as per their levels. Communication materials need to be packaged for different audiences, researchers, extension, agro-input dealers, fertilizer manufacturers, policy makers and the farmers. Experience in Uganda showed that when different stakeholders were involved in the roll out without proper packaging of the messages, there was contradictory given advice optimization approach.

Once the optimization approach and the supporting tools (FOT tools) are fully developed the next step of deploying them was considered critical. This was made possible through greater involvement of key stakeholders in researchers, extension, policy makers, and end users farmers through a process called taking research into use. Three major entry points were identified in this step. First was the participatory identification and engagement of key stakeholders in the fertilizer industry who are also strategic to create awareness and promote the Optimization approach. The country partners identify key stakeholders to be targeted in the stakeholder's engagement process and draw plans of action on activities. The stakeholders include development agencies e.g. NGOs, District Agricultural offices, Extension workers (Public and private), Agro dealers and fertilizer companies, Farmer groups-Cooperatives, Higher officials of Agriculture at regional and federal levels, Learning/research institutions , Researchers (international, regional and national) institutions (Table 3).

Communication is a critical component of rolling out the 


\section{Kenya Eastern Lower Fertilizer Use Optimizer: paper version Feb 2016}

The below assumes:

- Calibration measurement is with a i) Water bottle lid (lid) that holds about $6.2 \mathrm{~g}$ urea, $7.2 \mathrm{~g}$ DAP, and $8.25 \mathrm{~g} \mathrm{MOP}$ and ii) A $500 \mathrm{mls}$ water bottle of $5 \mathrm{~cm}$ diameter cut to height of $4 \mathrm{~m}$ has approx $80 \mathrm{ml}$ to hold $94 \mathrm{~g}$ urea, $113 \mathrm{~g}$ DAP, and $130 \mathrm{~g}$ MOP.

- It is assumed maize, Irish potatoes and sorghum are planted with $75 \mathrm{~cm}$ row spacing, and beans with $50 \mathrm{~cm}$ row spacing.

- It is assumed grain prices per kg (Ksh): 25 maize; 60 beans, 25 sorghum and 30 Irish potato.

- It is assumed $50 \mathrm{~kg}$ of fertilizer costs (Ksh): 2850 urea and 3600 DAP.

- Level 1 financial ability needs a benefit: cost ratio (BC) of 0.1-2; Level 2: BC 2 - 4; Level 3: BC >4.

- Application rates are in $\mathrm{kg} / \mathrm{ac}$.

- If any fertilizer rate application is less than $10 \mathrm{~kg} / \mathrm{acre}$ it is not economical and should be converted to another fertilizer.

\section{Level 1 financial ability}

- Irish potato: Apply $53 \mathrm{~kg}$ DAP (1 lid for $0.6 \mathrm{~m}$ ) by banding at planting.

\section{Level 2 financial ability}

- For maize, sidedress with $28 \mathrm{~kg}$ urea (1 lid for $1.0 \mathrm{~m})$ at $6 \mathrm{WAP}$.

- For beans, at planting band $21 \mathrm{~kg}$ DAP (1 lid for $2.4 \mathrm{~m})$ and sidedress with $12 \mathrm{~kg}$ urea (1 lid for $3.4 \mathrm{~m})$.

- For Irish potato, at planting band $61 \mathrm{~kg}$ DAP (1 lid for $0.5 \mathrm{~m})$.

\section{Level 3 financial ability (maximize profit per acre).}

- For maize, sidedress with $43 \mathrm{~kg}$ urea (1 lid for $0.6 \mathrm{~m})$ at $6 \mathrm{WAP}$.

- For beans, at planting band $30 \mathrm{~kg}$ DAP (1 lid for $1.7 \mathrm{~m})$ and sidedress with $17 \mathrm{~kg}$ urea (1 lid for $2.4 \mathrm{~m})$.

- For sorghum, at planting band $11 \mathrm{~kg}$ DAP (1 lid for 3.0m).

- For Irish potato, at planting band $61 \mathrm{~kg}$ DAP (1 lid for $0.5 \mathrm{~m})$.

Figure 6. Kenya Lower Eastern Paper based FOT.

optimization approach. OFRA partnered with ASHC in packing and communicating the optimization approach and the accompanying tools. Thirteen flyers specific to each of the 13 countries were developed to create awareness on the approach and the tools. Over 2000 of this were distributed targeting researchers, extension (public and private) agro dealers and progressive farmers. Consideration was made to adopt specific platforms for awareness creation in order to gunner maximum impact in terms of reach and clarity of the message. As such, we employed different platforms were used in awareness creation. Radios, print media (Daily Nation in Kenya, Daily Monitor in Uganda, Seeds of Gold in Kenya and Uganda), TV, Radio Africa in Tanzania, video documentaries of scientists discussing the preliminary results and potential impacts of the approach, lessons and case study development, national and international stakeholders forums, Country Soil Health Consortia (CSHC), Regional and international conferences.

\section{CONCLUSION AND RECOMMENDATIONS}

The optimization approach and supporting tools were developed for different AEZs in 13 countries in SSA. It is an innovation approach with the potential to change smallholder and resource poor farmers to be able to maximize their returns to investment in fertilizer. The approach will go a long way in creating a case of farmers' ability to make profits through farming as well as the policy formulators in planning for fertilizer subsidy 
Table 3. Stakeholders for the roll out of the optimization approach.

\begin{tabular}{|c|c|c|}
\hline Stakeholder & $\begin{array}{l}\text { Geographical } \\
\text { coverage }\end{array}$ & Major Roles/Mandate \\
\hline $\mathrm{CABI}$ & International & Communications, research†, data management, extension, coordination \\
\hline $\begin{array}{l}\text { University of Nebraska- } \\
\text { Lincoln }\end{array}$ & International & $\begin{array}{l}\text { Training, research, geo spatial analysis, science development, scientific } \\
\text { reporting }\end{array}$ \\
\hline Universities & National/regional & Training, research, education \\
\hline IFDC, CGIAR, IPNI, AGRA & International & $\begin{array}{l}\text { Funding, research, further development of the approach, improvement of } \\
\text { the FOTs }\end{array}$ \\
\hline NARS & National & Research, training, extension \\
\hline $\begin{array}{l}\text { African } \\
\text { associations }\end{array}$ & Regional & Research, further development of the approach, improvement of the FOTs \\
\hline AFSIS & Regional & Research and geospatial analysis \\
\hline Government & National & Policy, extension, resource mobilization \\
\hline Private sector & National/regional & Extension, enterprise development, credit facilities \\
\hline Farmer organizations & National/regional & Extension, credit facilities, resource mobilization, training farmers \\
\hline NGOs & $\begin{array}{l}\text { National and } \\
\text { international }\end{array}$ & Adaptive research, extension and training \\
\hline
\end{tabular}

programmes. However, it is recommended that researchers to work closely with farmers to validate the approach comparing the predicted versus actual. There is also need to further explore options of integrating the optimization approach with the input supply chain and also bringing in agricultural loan institutions as the approach provides the evidence that investment in fertilizer is profitable and would help in building a case to advance farmers loans. In other words the approach acts as a mini business plan to convince the bank to advance the loan.

\section{Conflict of Interests}

The authors have not declared any conflict of interests.

\section{REFERENCES}

Druilhe Z, Barreiro-Hurlé J (2012). Fertilizer subsidies in sub-Saharan Africa. ESA Working paper No. 12-04. Rome, FAO

Jansen J, Wortmann CS, Stockton MC, Kaizzi CK (2013). Maximizing net returns to financially constrained fertilizer use. Agron. J. pp. 573578.

Jayne TS, Rashid S (2013). Input subsidy programs in sub-Saharan Africa: a synthesis of recent evidence. Agric. Econ., 44(6):547-562.

Kaizzi CK, Byalebeka J, Semalulu O, Alou I, Zimwanguyizza W, Nansamba A, Musinguzi P, Ebanyat P, Hyuha T, Wortmann CS (2012b). Sorghum response to fertilizer and nitrogen use efficiency in Uganda. Agron. J. 104:83-90.

Kaizzi CK, Byalebeka J, Semalulu O, Alou I, Zimwanguyizza W, Nansamba A, Musinguzi $P$, Ebanyat $P$, Hyuha $T$, Wortmann CS (2012a). Maize response to fertilizer and nitrogen use efficiency in Uganda. Agron. J. 104:73-82.

Kaizzi CK, Byalebeka J, Wortmann CS, Mamo M (2007a). Low Input Approaches for Soil Fertility Management in Semiarid Eastern Uganda. Agron. J. 99:847-853.

Kaizzi CK, Ssali H, Nansamba A, Paul LG, Vlek (2007b). The Potential benefits of Azolla, Velvet bean (Mucunapruriens) and $\mathrm{N}$ fertilizers in rice production under contrasting systems of eastern Uganda. In: Bationo A, Kihara J, Kimetu J, Waswa B (eds.). Advances in Integrated Soil Fertility Research in Sub-Saharan Africa: Challenges and Opportunities, Springer. The Netherlands pp. 423-433.

Kaizzi CK, Ssali H, Vlek PL (2006). Differential use and benefits of Velvet bean (Mucuna pruriens var. utilis) and $\mathrm{N}$ fertilizers in maize production in contrasting agro-ecological zones of E. Uganda. Agric. Syst. 88(1):44-60.

Kaizzi CK, Ssali H, Vlek PLG (2004). The potential of Velvet bean (Mucunapruriens) and $\mathrm{N}$ fertilizers in maize production on contrasting soils and agro-ecological zones of eastern Uganda. Nutr. Cycling Agroecosyst. 68:59-72.

Kaizzi CK, Wondimu B, Rware H, Macharia M, Wortmann CS (2015). Optimizing fertilizer recommendations in Africa. The 28th bi-annual conference of the soil science society of east Africa (SSSEA) \& African celebration meeting of the international year of soil, Mororgoro, Tanzania, 23rd to 27th November 2015

Kaizzi CK, Wortmann C, Byalebeka J, Semalulu O, Alou I, Zimwanguyizza W, Nansamba A, Musinguzi $P$, Ebanyat $P$, Hyuha T (2012c). Optimizing smallholder returns to fertilizer use: bean, soybean and groundnut. Field Crops Res. 127:109-119.

Kaizzi CK, Wortmann CS (2001). Plant Materials for Soil Fertility Management in Subhumid Tropical areas. Agron. J. 93:929-935.

Rware H, Wairegi L, Oduor G, Macharia M, Romney D, Tarfa BD, de Maria R, Ley G, Tetteh F, Makumba W, Dicko M (2014). Assessing the Potential to Change Stakeholders Knowledge and Practices on Fertilizer Recommendations in Africa. Agric. Sci. 5(14):1384.

Suri T (2011). Selection and comparative advantage in technology adoption. Econ. 79(1):159-209.

World Bank (2007). Fertilizer Use in African Agriculture: Lessons Learned and Good Practice Guidelines

Wortmann CS, Kaizzi CK (2000). Tree legumes in medium-term fallows: Nitrogen Fixation, Nitrate recovery and effects on subsequent crops. Afr. Crop Sci. J. 8:263-272.

Wortmann CS, Ssali H (2001). Integrated nutrient management for resource-poor farming systems: A case study of adaptive research and technology dissemination in Uganda. Am. J. Alt. Agric. 16:161167. 